\title{
ANALISIS FAKTOR PENYEBAB TERJADINYA DUPLIKASI REKAM MEDIS DI BAGIAN RAWAT JALAN DI RUMAH SAKIT X
}

\author{
Hanifah Aulia Rahayu ${ }^{1 *}$, Sri Mulyaningsih ${ }^{2}$, Yuyun Yunengsih ${ }^{3}$ \\ Politeknik Piksi Ganesha Bandung ${ }^{1,2,3}$ \\ harahayu@piksi.ac.id ${ }^{1 *}$, msulyaningsih@piksi.ac.id ${ }^{2}$,yoen1903@gmail.com ${ }^{3}$
}

Received: 02-08-2021

Revised : 20-10-2021

Accepted: 21-10-2021

\begin{abstract}
Abstrak
Latar Belakang: Salah satu sistem dari penyelenggaraan rekam medis dimana semua pasien yang datang ke instansi pelayanan kesehatan diberikan suatu nomor rekam medis yang berfungsi sebagai salah satu identitas pasien yang membedakan antara pasien satu dengan yang lainnya. Sistem penomoran rekam medis ada tiga yaitu seri,unit,dan seri unit. di Rumah Sakit X menggunakan sistem penomoran unit numbering system yaitu setiap pasien yang berobat hanya memiliki satu nomor rekam medis untuk selamanya, selama pasien tersebut berkunjung ke suatu institusi kesehatan dan sistem pengajarannya menggunakan straight numerical filing.

Tujuan: Tujuan penelitian ini yaitu untuk mengetahui faktor - faktor terjadinya duplikasi rekam medis di rawat jalan Rumah Sakit X pada tahun 2021.
\end{abstract}

Metode: Penelitian ini merupakan jenis penelitian deskriptif dan metode pendekatan kuantitatif.

Hasil: Hasil penelitian diperoleh bahwa jumlah kunjungan di Rumah Sakit X pada tahun 2021 sebanyak 20431 kunjungan. rekam medis yang terjadi duplikasi sebanyak 74 rekam medis dan jumlah yang tidak terduplikasi sebanyak 20357.

Kesimpulan: Berdasarkan dari hasil penelitian dapat disimpulkan bahwa jika petugas rekam medis di bagian pendaftaran rawat jalan tidak memperhatikan kinerjanya maka tidak akan terjadi duplikasi terhadap rekam medis pasien.

Kata kunci: duplikasi; rekam medis; rumah sakit; rawat jalan.

\begin{abstract}
Background: One of the systems of administering medical records where all patients who come to health care agencies are given a medical record number that serves as one of the patient identities that distinguishes one patient from another. There are three medical record numbering systems, namely series, unit, and unit series. Hospital X uses a unit numbering system, that is, every patient seeking treatment only has one medical record number forever, as long as the patient visits a health institution and the teaching system uses straight numerical filing.
\end{abstract}




Objective: The purpose of this study is to determine the
factors of duplication of medical records in outpatient
Hospital $X$ in 2021 .
Methods: This research is a descriptive type of research
and a quantitative approach method..
Results: The results showed that the number of visits at
Hospital $X$ in 2021 was 20431 visits. There were 74
duplicate medical records and 20357 unduplicated medical
records.
Conslusion: Based on the results of the study, it can be
concluded that if the medical record officer in the outpatient
registration section does not pay attention to their
performance, there will be no duplication of the patient's
medical record.
Keywords: duplication; medical record; hospital;
outoatient.
*Correspondent Author : Hanifah Aulia Rahayu
Email : harahayu @ piksi.ac.id

\section{PENDAHULUAN}

Menurut Undang - undang no 44 tahun 2009 bahwa rumah sakit adalah institusi pelayanan kesehatan yang menyelenggarakan pelayanan kesehatan perorangan secara paripurna yang menyediakan pelayanan rawat inap, rawat jalan dan gawat darurat (Permenkes, 2009). Rekam medis menurut permenkes No.749a/Menkes/Per/XII/1989, rekam medis adalah berkas yang berisikan catatan dan dokumen tentang identitas pasien, pemeriksaan, pengobatan,tindakan dan pelayanan kepada pasien pada sarana pelayanan kesehatan (Jenny, 2013).

Unit rekam medis melingkupi penerimaan pasien sampai dengan penyajian informasi kesehatan. Tugas unit rekam medis mulai dari pengumpulan data, pemprosesan data, dan penyajian informasi kesehatan data yang dikumpulkan berupa data sosial dan data medis. Proses pengumpulan data pertama kali di suatu fasilitas pelayanan kesehatan dilakukan di unit rekam medis pada urusan penerima pasien. data di tempat penerimaan pasien di jadikan sebagai sumber data pasien yang berobat di klinik, bangsal,atau pelayanan penunjang (Yolanda, 2019). Setelah mendapatkan masukan data dari penerimaan pasien dan bagian pelayanan medis data diproses melalui tahapan penyusunan, pengecekan, kelengkapan, pengkodean, pengindeksan, dan rekap laporan (Abqoria \& Masturoh, 2016).

Tujuan rekam medis adalah menunjang tercapainya tertib administrasi dalam rangka upaya peningkatan pelayanan kesehatan rumah sakit. Hal ini harus didukung oleh sistem penyelenggaraan rekam medis yang baik dan benar. Tertib administrasi merupakan salah satu faktor yang menentukan dalam upaya pelayanan kesehatan di rumah sakit. Pembuatan rekam medis di rumah sakit bertujuan untuk mendapatkan catatan atau dokumen yang akurat dari pasien, mengenai sekarang juga pengobatan yang telah diberikan sebagai upaya peningkatan pelayanan kesehatan (Rustiyanto, 2009).

Seorang perekam medis dan informasi kesehatan (PMIK) juga penting untuk memperhatikan cara pemberian nomor rekam medis. Sistem dalam pelayanan rekam medis yaitu tata cara penulisan nomor yang diberikan kepada pasien yang datang berobat sebagai bagian dari identitas pribadi pasien yang bersangkutan. Sebelum diberlakukan nya nomor rekam medis di fasilitas pelayanan Kesehatan, dahulu di rumah sakit menyimpan dokumen rekam medis pasien itu berdasarkan nama pasien, nomor keluar atau discharge number dan 
kode diagnosis namun dengan penggunaan nama pasien dengan huruf sangat menyulitkan untuk mencari dokumen rekam medis pasien, maka gantilah dengan memberlakukan nomor bukan huruf untuk memudahkan dalam penyimpanan dan menghindari kesalahan. Sistem penomoran dalam pelayanan rekam medis yaitu tata cara penulisan nomor yang diberikan kepada pasien yang datang berobat sebagai bagian dari identitas pribadi pasien yang bersangkutan (Hakam, 2019).

Bagi pasien lama yang tidak membawa KIB pada saat berobat petugas biasanya melakukan pendaftaran dengan menggunakan kartu identitas pasien seperti KTP, KK dan kartu BPJS atau asuransi lain nya untuk mengetahui pasien baru atau lama jika tidak menemukan rekam medisnya maka dibuatkan rekam medis baru. Duplikasi penomoran yang terjadi disebabkan oleh proses identifikasi yang kurang tepat sehingga menyebabkan pasien mendapatkan lebih dari satu nomor rekam medis. Duplikasi adalah perulangan, keadaan rangkap. Sedangkan rangkap adalah dua tiga helai melekat menjadi satu, bila ditemukan pasien memiliki lebih dari satu nomor rekam medis maka berkas tersebut harus digabungkan menjadi satu nomor (Muldiana, 2016).

Berdasarkan pengalaman praktik kerja lapangan (PKL) di Rumah Sakit X ditemukannya suatu masalah yaitu terjadinya duplikasi nomor rekam medis pada berkas pasien lama. Dan setelah melakukan observasi terdapat duplikasi pada rekam medis setiap bulannya. Berdasarkan sistem penomoran yang diterapkan di Rumah Sakit X yaitu menggunakan unit numbering system maka diharuskan seorang pasien hanya bisa mendapatkan satu nomor rekam medis untuk selamanya baik digunakan pada bagian rawat jalan, rawat inap dan instalasi gawat darurat.

\section{METODE PENELITIAN}

Jenis penelitian yang dilakukan adalah menggunakan metode kuantitatif deskriptif yaitu jenis penelitian yang digunakan untuk menganalisis data dengan cara mendeskripsikan atau menggambarkan data yang telah terkumpul sebagaimana adanya dan Teknik pengumpulan data yang dipakai adalah dengan cara observasi dan wawancara. Populasi yang diambil dari rekam medis yang terjadi duplikasi pada bulan januari sampai - mei 2021.

Penelitian deskriptif dilakukan untuk mendeskripsikan suatu gejala, peristiwa, dan kejadian yang terjadi secara faktual,sistematis, dan akurat. Penelitian ini mendeskripsikan peristiwa yang terjadi pada saat melakukan praktek kerja lapangan (PKL) di Rumah Sakit $\mathrm{X}$. Penelitian yang di lakukan ini untuk mengetahui faktor terjadinya duplikasi rekam medis di Rumah Sakit X. Penelitian ini mendeskripsikan peristiwa yang terjadi pada saat melakukan praktek kerja lapangan (PKL) di Rumah Sakit X pada tanggal 14 April - 14 Juni 2021.

\section{HASIL DAN PEMBAHASAN}

\section{A. Hasil Penelitian}

Sistem penomoran yang diterapkan di Rumah Sakit X yaitu unit numbering system. Sistem ini merupakan sistem informasi klinis yang dapat berkesinambungan karena semua data dan informasi mengenai pasien dan pelayanan yang diberikan berada dalam satu folder. Jumlah petugas pendaftaran rawat jalan ada 9 petugas. Berdasarkan hasil observasi ditemukannya beberapa duplikasi RM pada setiap bulannya. 
Tabel 1. Jumlah duplikasi RM Pada Bulan Januari - Mei 2021

\begin{tabular}{llccc}
\hline No & Bulan & $\begin{array}{c}\text { Jumlah } \\
\text { kunjungan }\end{array}$ & $\begin{array}{c}\text { Jumlah RM } \\
\text { duplikasi }\end{array}$ & $\begin{array}{c}\text { Jumlah RM yang tidak } \\
\text { duplikasi }\end{array}$ \\
\hline 1 & Januari & 3605 & 12 & 3593 \\
\hline 2 & Februari & 3617 & 16 & 3601 \\
\hline 3 & Maret & 4588 & 10 & 4578 \\
\hline 4 & April & 4426 & 17 & 4409 \\
\hline 5 & Mei & 4195 & 19 & 4176 \\
\hline & Total & 20431 & 74 & 20357 \\
\hline
\end{tabular}

Berdasarkan pada tabel 1 di atas, faktor - faktor yang menyebabkan duplikasi Rekam Medis diantaranya pada saat ada pasien baru, penulisan identitas nama tidak sesuai dengan identitas sebelumnya, identitas pasien sebelumnya masih menggunakan nama By. Ny, jika ada pasien baru petugas tidak mengecek terlebih dahulu di SIM RS apakah pasien tersebut benar pasien baru bukan.

\section{B. Pembahasan}

Berdasarkan hasil penelitian tentang duplikasi pada berkas rekam medis bahwa petugas pendaftaran rawat jalan yang berjumlah 9 petugas masih kurang teliti ketika mendaftarkan pasien rawat jalan sehingga terjadi duplikasi nomor rekam medis. Sistem penomoran dalam pelayanan rekam medis yaitu tata cara penulisan nomor yang diberikan kepada pasien yang datang berobat sebagai bagian dari identitas pasien yang bersangkutan.

Sistem penomoran rekam medis pasien bertujuan untuk:

1. Pemberian nomor secara serial numbering system yaitu sistem penomoran dimana setiap pasien yang berkunjung ke rumah sakit atau puskesmas selalu mendapatkan nomor baru keuntungan menggunakan sistem ini petugas lebih mudah mengerjakannya. kerugiannya membutuhkan waktu yang lama untuk mencari atau mendapatkan berkas rekam medis pasien lama karena satu pasien mendapatkan lebih dari satu nomor rekam medis sehingga informasi pelayanan klinisnya menjadi tidak berkesinambungan dan dapat merugikan pasien.

2. Petunjuk folder dokumen rekam medis dalam menyimpan artinya dijadikan pedoman dalam tata cara penyimpanan dokumen rekam medis.

3. Memudahkan dalam pencarian dokumen rekam medis yang telah tersimpan di filing. Karena nomor rekam medis yang tersimpan tercatat dalam buku register dan tracer yang akan membantu untuk mencari dokumen rekam medis,yang meminjam dan waktu peminjaman dokumen rekam medis dan membantu kembali menyimpan dokumen rekam medis.

Menurut (Mathar, 2018) dalam buku rekam medis ada tiga sistem pemberian nomor pasien (administration numbering system) adalah sebagai berikut:

1. Pemberian nomor secara serial numbering system yaitu sistem penomoran dimana setiap pasien yang berkunjung ke rumah sakit atau puskesmas selalu mendapatkan nomor baru keuntungan menggunakan sistem ini petugas lebih mudah mengerjakannya. Kerugiannya membutuhkan waktu yang lama untuk mencari atau mendapatkan berkas rekam medis pasien lama karena satu pasien mendapatkan lebih dari satu nomor rekam medis sehingga informasi pelayanan klinis nya menjadi tidak berkesinambungan dan dapat merugikan pasien.

2. Pemberian secara unit numbering system yaitu sistem penomoran dimana sistem ini memberikan satu nomor rekam medis pada pasien berobat jalan, pasien rawat inap, gawat darurat dan bayi baru lahir. Keuntungan sistem ini yaitu informasi klinis dapat berkesinambungan tetapi pengambilan data pasien akan lebih lama karena semua data dan informasi mengenai pasien dan pelayanan pendaftaran pasien pernah berkunjung 
(berobat) atau sebagai pasien lama hanya memiliki satu nomor. Kekurangan ini dapat diatasi dengan sistem pelayanan terpisah antara pendaftaran pasien lama atau baru.

3. Pemberian nomor secara seri unit numbering system yaitu sistem penomoran dengan menggabungkan sistem seri dan sistem unit setiap pasien yang berkunjung pada sarana pelayanan kesehatan diberikan nomor baru tetapi dokumen rekam medis terdahulu digabungkan dan di simpan jadi satu di bawah nomor yang paling baru. kekurangannya dari pemberian nomor dengan sistem seri unit numbering system yaitu petugas mengalami kerepotan setelah pelayanan dan informasi klinis tidak berkesinambungan.

Berdasarkan sistem penomoran yang telah diterapkan di Rumah Sakit X yaitu menggunakan unit numbering system maka diharuskan seorang pasien hanya bisa mendapatkan satu nomor rekam medis untuk selamanya baik digunakan pada bagian rawat jalan, rawat inap, dan gawat darurat (Gultom \& Pakpahan, 2019). Berdasarkan hasil observasi faktor - faktor yang menyebabkan terjadinya duplikasi nomor rekam medis yaitu:

1. Pada saat ada pasien baru, penulisan identitas nama tidak sesuai dengan identitas sebelumnya.

2. Identitas pasien sebelumnya masih menggunakan nama By.Ny

3. Jika ada pasien baru petugas tidak mengecek terlebih dahulu di SIM RS apakah pasien tersebut benar pasien baru atau bukan.

Bagi pasien lama yang tidak membawa KIB pada saat berobat petugas biasanya melakukan pendaftaran dengan menggunakan kartu identitas pasien seperti KTP, KK dan kartu BPJS atau asuransi lain nya untuk mengetahui pasien baru atau lama jika tidak menemukan rekam medisnya maka dibuatkan rekam medis baru. Berdasarkan SOP yang telah diterapkan di Rumah Sakit X untuk penyimpanan rekam medis pasien yang terjadi duplikasi yaitu apabila data pasien sama, petugas pendaftaran mengambil semua rekam medis di ruang penyimpanan/distribusi (Nugroho, 2012). Petugas pendaftaran mengecek isi rekam medis tersebut apakah identitasnya sama. Apabila sama maka selanjutnya petugas mengecek Riwayat pengobatan setiap rekam medis tersebut, gunakan nomor rekam medis yang memiliki riwayat pengobatannya paling banyak. Petugas menggabungkan semua rekam medis double tersebut menjadi satu. Petugas menghubungi tim IT untuk menggabungkan nomor rekam medis dan Riwayat pengobatan pasien tersebut ke nomor rekam medis yang digunakan di SIM RS. Petugas mengecek ulang nomor rekam medis yang sudah digabungkan di SIM RS untuk memastikan apakah rekam medis tersebut sudah tergabung (Januraga et al., 2021).

Sistem penyimpanan yang digunakan di Rumah Sakit X yaitu menggunakan sistem sentralisasi adalah semua berkas rekam medis pasien disimpan dalam satu berkas dan satu tempat, baik untuk rawat jalan ,rawat inap, maupun instalasi gawat darurat (Kusnadi et al., 2018). Kelebihannya menggunakan sistem ini adalah mengurangi terjadinya duplikasi dalam pemeliharaan dan penyimpanan, mengurangi jumlah pembiayaan untuk peralatan dan pembuatan ruangan, peningkatan efisiensi petugas dalam penyimpanan atau penemuan Kembali dokumen rekam medis, lebih efektif di dalam pelaksaan koordinasi dan control di dalam penyimpanan, penggunaan alat dan prosedur lebih mudah di seragamkan, memudahkan di dalam pelaksanaan penyusutan dokumen rekam medis, lebih mudah dalam menjaga hubungan data baik data rawat jalan,rawat inap, dan instalasi gawat darurat (Kristina, 2015).

\section{KESIMPULAN}

Berdasarkan hasil penelitian dapat disimpulkan bahwa pada masa pandemic COVID-19 seperti ini pelayanan pendaftaran rawat jalan mengalami kekurangan petugas dikarenakan sebagian petugas mengalami kelelahan akibat banyaknya pasien yang datang 
berobat di Rumah Sakit X sehingga petugas pendaftaran menjadi kurang teliti dan menyebabkan terjadinya duplikasi pada nomor rekam medis sebanyak 74 berkas rekam medis yang mengalami duplikasi pada tahun 2021 di bulan Januari sampai dengan Mei. Untuk mengurangi terjadinya duplikasi petugas diharapkan untuk lebih teliti lagi pada saat mendaftarkan pasien baru dan bekerja sesuai prosedur yang berlaku.

\section{BIBLIOGRAFI}

Abqoria, R. N., \& Masturoh, I. (2016). Gambaran Pelaporan Internal Di Rumah Sakit Umum Daerah. Media Informasi, 12(2), 88-94. https://doi.org/10.37160/bmi.v12i2.57

Ferdiansyah, R., \& Rudiarto, I. (2021). Tingkat Ketahanan Komunitas Terhadap Risiko Banjir Rob Di Kecamatan Wonokerto, Kabupaten Pekalongan. UNIVERSITAS DIPONEGORO.

Gultom, S. P., \& Pakpahan, E. W. (2019). Faktor-Faktor Yang Memengaruhi Duplikasi Penomoran Rekam medis Di Rumah Sakit Umum Madani Medan. Jurnal Ilmiah Perekam Dan Informasi Kesehatan Imelda (JIPIKI), 4(2), 604-613.

Hakam, F. (2019). Implementasi Manajemen Rekam Medis Di Rumah Sakit Pku Muhammadiyah Yogyakarta. Jurnal Manajemen Informasi Dan Administrasi Kesehatan (JMIAK), 2(1). https://doi.org/10.32585/jmiak.v2i01.444

Januraga, P. P., Wirawan, G. B. S., Harjana, N. P. A., \& Ulandari, L. P. S. (2021). Rekam Kesehatan Elektronik: Kajian Model dan Prototipe Sistem Informasi Kesehatan untuk Industri 4.0. Bali, Indonesia. Baswara Press.

Jenny, M. (2013). Evaluasi sistempelaksanaan rekammedis rawat inap bedah di rsup $d r$. M. Djamil padang tahun 2013. Universitas Andalas.

Kristina, I. (2015). Tinjauan Penyimpanan Rekam Medis di Klinik Prodia Occupational Health Center Jakarta Selatan. MEDICORDHIF Jurnal Rekam Medis, 2, 52.

Kusnadi, D., Yuli Kusumawati, S. K. M., \& Sri Sugiarsi, S. K. M. (2018). Analisis Penyimpanan Dokumen Rekam Medis RS. Ortopedi. Prof. Dr. R. Soeharso Surakarta. Universitas Muhammadiyah Surakarta.

Mathar, I. (2018). Manajemen Informasi Kesehatan: Pengelolaan Dokumen Rekam Medis. Deepublish.

Muldiana, I. (2016). Analisis Faktor-Faktor Yang Mempengaruhi Duplikasi Penomoran Rekam Medis Di Rumah Sakit Atma Jaya 2016. Indonesian of Health Information $\begin{array}{llll}\text { Management Journal } & \text { (INOHIM), }\end{array}$ https://doi.org/10.47007/inohim.v4i2.148

Nugroho, S. J. (2012). Enterprise architecture planning sistem informasi RSIA Andini dengan menggunakan TOGAF. Universitas Islam Negeri Sultan Syarief Kasim Riau.

Permenkes. (2009). Undang-Undang RI No. 44 Tahun 2009 Pasal 1.

Rustiyanto, E. (2009). Etika profesi perekam medis dan informasi kesehatan. Yogyakarta: Graha Ilmu.

Sugiyono. (2017). Bandung: Alfabeta. Sugiyono.(2017). Metode Penelitian Kuantitatif Kualitatif Dan R\&D.

Yolanda, D. R. (2019). Analisis Sistem Pelayanan Administrasi dalam Penerimaan Pasien BPJS di Ruang Instalasi Gawat Darurat Rumah Sakit Umum Daerah H. Andi Sultan Daeng Radja Kabupaten Bulukumba Tahun 2018. Universitas Islam Negeri Alauddin Makassar.

(C) 2021 by the authors. Submitted for possible open access publication under the 